\title{
DETERMINANTS OF THE STRUCTURE OF U.S. FOREIGN TRADE, 1958-76
}

\author{
Robert M. STERN* and Keith E. MASKUS \\ University of Michigan. Ann Arhor, MI 48109, USA
}

Received January 1980, revised version received November 1980

The Heckscher-Ohlin model with three direct-factor inputs is brrne out for U.S. net exports of manufactures in annual cross-section regressions for 1958.76 . 7 he coefficient on unskilled labor became significantly more negative over the period, and there is evidence that the negative sign on physical capital may reflect the inclusion of natural resource industries. Further analysis based upon 1960 and 1970 census years suggests the importance as well of skill and technological variables. Calculations of the total factor requirements of U.S. trade uphold the Leontief paradox for 1958 but not for 1972.

\section{Introduction}

In this paper we analyze changes in the determinants of the structure of U.S. foreign trade over the period 1958-76. Our analysis rests mostly on the factor-content version of the Heckscher-Ohlin model, and we use both regression procedurts and Leontief-type calculations based upon inputoutput data. We begin with a model of trade in manufactures in which there are three direct-factor inputs: physical capital, human capital, and unskilled labor. We then introduce more refined measures of human capital together with some technological variables. Finally, we consider direct plus indirect factor inputs and trade in both manufactures and nonmanufactures.

Most previous studies have focused on the determinants of trade in only one particular year. For example, Baldwin (1971) and Harkness and Kyle (1975) analyzed 1962 trade using 1958 industry characteristics, and Hufbauer (1970) and Branson and Monoyios (1977) focused on 1963. Except for

\footnotetext{
*An earlier version of this paper was presented at the Winter Meetings of the Econometric Society in Atlanta in December 1979. We are indebte $i$ to Alan V. Deardorff, Saul H. Hymans, Edward E. Leamer, Jeffrey Pliskin, Rachel McCulloch, and members of the Research Seminar in International Economics at the University of Michigan for helpful comments. Michael Dompierre was instrumental in constructing and updating the data base. We are grateful also to Prachaya Jumpasut, Christopher Baum, and Willa Ann Cohen for their assistance in data compilation and processing. Werner Riedl and Mark Greene are to be thanked for their computational advice. The research underlying this paper was financed primarily by a grant frum the General Electric Foundation.
} 
Branson and Monoyios who checked their 1963 results against data for 1967, there have to our knowledge been no systematic efforts heretofore to analyze the structural determinants of U.S. trade at different points in time and for a long enough period to detect what changes, if any, may have occurred.

\section{Changes in U.S. net exports of manufactures, 1958-76}

Some indication of the behavior of net exports of manufactures from 1958 to $\mathbf{1 9 7 6}$ is given in fig. $\mathbf{1}$. The nominal trade balance for all manufactures was positive and stable from 1958 to 1964 . It fell thereafter and reached a low point in 1972 , after which time it increased substantially. In order to provide additional perspective on the behavior of net exports, we disaggregated U.S.

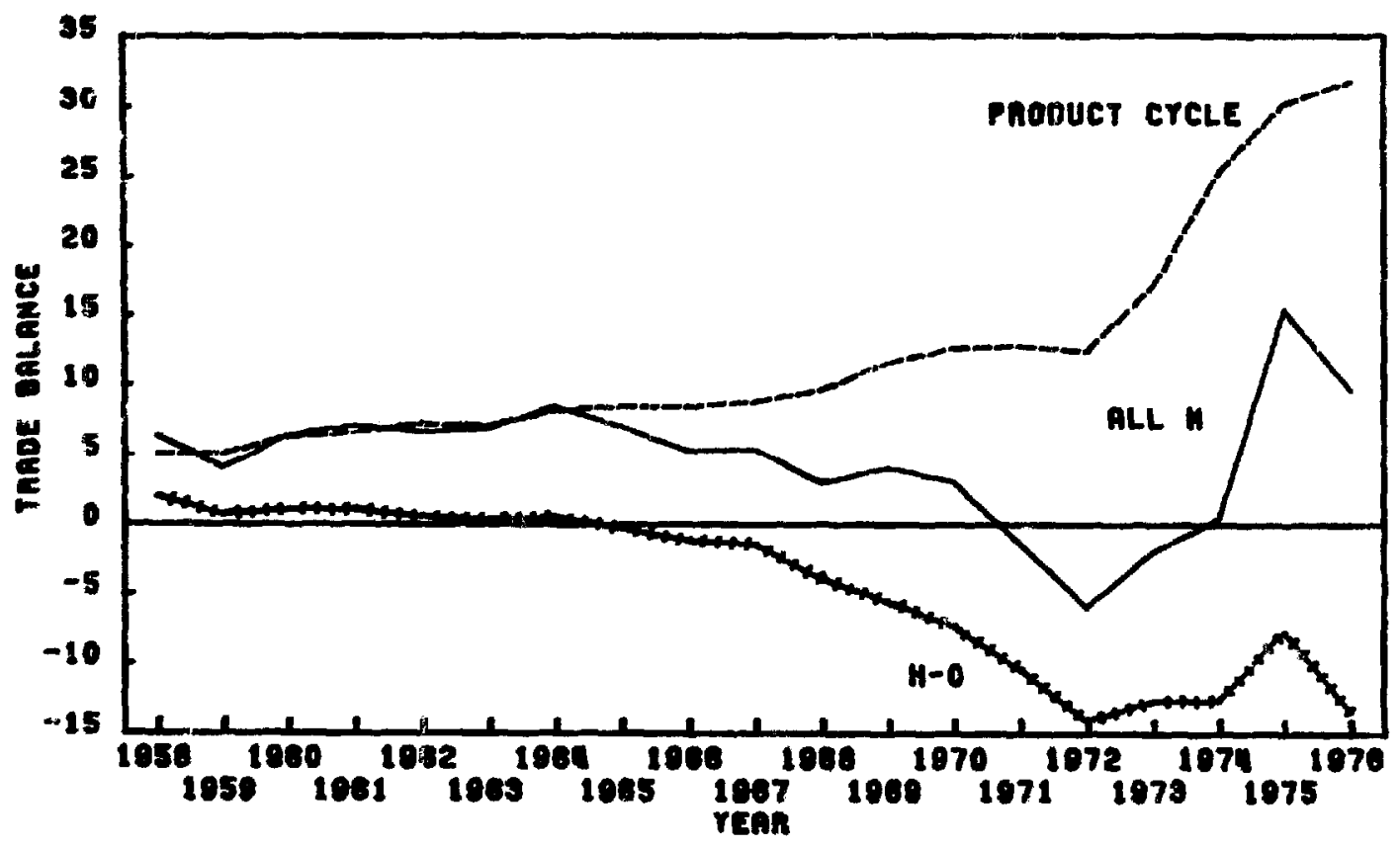

Fi. I. U.S. trade balances for all manufactures, Heckscher-Ohlin industries, and Product Cycle industries, 1958-76 (billions of carrent dollars).

trade in manufactures by three-digit SIC industry groups and then classified each industry by its cconomic characteristics into three major groups. For this latter purpose we followed Hufbauer and Chilas (1974, pp. 35-38), who divided U.S. trade into Ricardo goods, Heckscher-Ohlin goods, and Product Cycle goods. Broadly speaking, Ricardo goods are characterized in production by their natural resource component, Heckscher-Ohlin goods by the use of standardized technology, and Product Cycle goods by the use of advanced technology.

The annual net exports for the Heckscher-Ohlin and Product Cycle industries are plotted in fig. 1 for 1958-76. It is noteworthy that U.S. net 
exports of Heckscher-Ohlin goods declined continuously during most of the period, reaching a level of $-\$ 13.3$ billion in 1976. In contrast, net exports of Product Cycle goods increased more or less steadily from 1958 to 1972 and then turned sharply upward, reaching a level of $\$ 31.8$ billion in 1976. Net exports of Ricardo goods, which are not plotted separately in fig. 1, were fairly constant until 1973 and declined substantially thereafter, reaching a level of $-\$ 9.2$ billion in 1976 due primarily to increased imports of fuels and lubricants.

It would certainly be interesting to analyze the behavior of each of the three subgroups separately, but our preliminary efforts to do so proved to be diseppointing. We shall concentrate in the following sections therefore on tracle in manufactures in the aggregate, although $w^{\text {s }}$ shall have occasion to eliminate Ricardo goods to determine how these nat ural resource industries may affect the results.

\section{Theoretical considerations}

The classification of industries into Ricardo, Heckscher-Ohlin, and Product Cycle goods is suggestive of the major forces that shape a nation's comparative advantage. Thus, climatic differences and the uneven distribution of minerals and other natural resources are the major influences on a country's net exports of Ricardo goods. Differences in factor endowments - physical capital, human capital, and unskilled labor - are the main determinants of trade in Heckscher-Ohlin goods. Finally, technological differences and the availability of new and improved products and processes are the primary forces shaping a country's net exports of Product Cycle goods.

For purposes of analysis, it would be desirable to have a model that encompassed all of the influences just mentioned. Ther: have of course been efforts to combine theoretically the static comparative costs model based upon technological differences with the Heckscher-Ohlin model based upon differences in factor endowments, It has proven difficult, however, to integrate these models rigorously with a model of the product cycle which rests more upon dynamic considerations. It is interesting that empirical researchers have nonetheless proceeded to 'test' these models even though the hypotheses involved could not be derived rigorously from an underlying theoretical model. We are cognizant of this gap between theory and empiricism, but it is not our intention to deal with it.

In the next section we begin with a stylized version of the HcckscherOhlin model in which it is assumed that there are three direct-factor inputs that are used in the production and trade of $n$ manufactured goods. We will use regression analysis to test this factor-content version of the HeckscherOhlin model across all manufacturing industries. We will then carry out a 
probit analysis based upon the commodity version of the Heckscher-Ohlin model which distinguishes "itural resource (Ricardo) industries from other manufacturing industries. " attempt subsequently to introduce technological (product cycle) influences into our regression analysis. Finally, we revert back to the three-input model and examine the factor content of U.S. trade in manufacttires and non-manufactures using input-output data that include both direct plus indirect factor inputs.

\section{Direct factor inputs in U.S. trade in manufactures}

As just stated, we shall begin with a three-direct-factor input version of the Heckscher-Ohlin model. It is assumed that this model applies across all industries and that indirect inputs can be ignored. The model is as follows:

$$
N X_{\mathrm{it}}=f\left(K_{\mathrm{it}}, H_{i \mathrm{it}}, L_{i t}\right)
$$

where $N X_{i t}$ is net exports $\left(X_{i t}-M_{i t}\right)$ of the $i$ th three-digit SIC industry group at time $t, K_{i t}$ is each industry's stock of physical capital, $H_{i t}$ is the stock of human capital, and $L_{i t}$ is industry employment. This model was estimated for a cross section of U.S. industries for 1963 and 1967 by Branson and Monoyios (1977), and we have adopted their specification in order to make our results comparable to theirs. ${ }^{1}$ While the signs of the variables cannot be determined a priori, the results obtained by Branson and Monoyios and others suggest a negative sign for $K_{i t}$ to the extent that the Leontief paradox may be present, a positive sign for $H_{i t}$ reflecting the relative abundance of human capital in the U.S., and a negative sign for $L_{i t}$ reflecting the relative scaicity of unskilled labor.

Data for all of these variables were constructed for the three-digit SIC industries on an annual basis for the period 1958-76. While the data for $N X_{i t}, K_{i n}$, and $L_{i n}$ were taken from the sources cited in the appendix below, the stock of human capital was calculated, follcwing Branson and Monoyios, as the discounted industry-wage differential:

$$
H_{i t} \equiv \frac{\left(\tilde{W}_{i t}-\tilde{W}_{t}\right) \cdot L_{i t}}{0.10}
$$

where $\bar{W}_{i t}$ is the average annual wage for each industry at time $t, W_{t}$ is the median annual wage for all workers with eight years or less of education, $L_{i t}$ is industry employment, and the rate of discount used is 10 percent. In order

'Stern (1976) also applied this model to West Germany for 1962 and 1969. 
to permit comparisons across years, all variables were expressed in constant (1967) prices.

\subsection{Cross-section results for 1958-76}

For reasons specificd in Branson and Monoyios (1977) and Harkness and Kyle (1975), we may expect the presence of heteroskedasticity in our data sample. That is to say, the variance of the disturbance term implicit in a linear form of eq. (1) is likely to increase with indus ry size. Accordingly, we first estimated eq. (1) for each annual cross section and then tested for the presence of heteroskedasticity, which was conlirmed. 'The standard procedure for correcting for this problem is to scale the rugression by an appropriate industry-size factor. In choosing such a scale variable the valuc of industry shipments. $S_{i t}$, would appear to be the logical choice on homogeneity grounds. But from the econometric standpoint, it is appropriate to scale by the variable to which the standard deviation of the regression disturbance is believed proportional. We identified this variable by regressing the absolute value of the residuals from a full-sample unscaled regression on alternative size measures, such as $S_{i t}, S_{i t}^{\frac{1}{2}}$, and $S_{i t}^{2}$, and choosing the one that fit best. This turned ou: to be the square root of shipments, $S_{i t}^{2}{ }^{2}$

We then scaied all variables for each year by dividing them through $\mathrm{t}$ y $S_{i t}^{\frac{1}{2}}$ and re-ran the regressions. The results of the scaled regressions are summarized in table $1 .^{3}$ It will be noted that these regressions include the variable, $S_{i t}^{-\frac{2}{2}}$, which corresponds to the constant term of the unscaled regressions. ${ }^{4}$ The number of three-digit industries varied slightly from year to year because of missing data. The levels of significance are indicated as $*(0.05)$ and $* *(0.01)$, and $t$-values are reported in parentheses.

It is evident that all the variables conformed to the signs noted above. The human-capital variable was significant throughout at the 0.01 level, the physical capital variable at the 0.01 or 0.05 level for all years except 1964 , 1970,1972 , and 1973, and the employment variable for all years except 1958

${ }^{2}$ A different scaling factor was suggested in a few instances, but we decided to use $S_{i t}^{1}$ throughout in order to maintain consistency among years. Branson and Monoyios also chose $S$ as their scale variable.

${ }^{3}$ Branson and Monoyios (1977, p;). 117 and 119) present regression results for 1963 and 1967 based upon unscaled and scaled variables. Because the coeflicients on the $K, H$, and $L$ variables are more or less the same and are statistically significant in the urscaled and scaled regression, Branson and Monoyios conclude that scaling does not alter the basic results. This conclusion is not correct strictly speaking, however, because the standard errors are noticeably higher in the scaled regressions. In our view, once heteroskedasticity is suspected and found to be present, it is only the scaled regressions that are of interest. Therefore, scaling does matter to the results.

${ }^{4}$ Branson and Monoyios (1977, p. 119) report a new constant term in their scaled regressions, which is improper. Since the original data matrix, including the constant term, was sialed by $S^{!}$, their scaled regressions should have been estimated without an intercept. As a consequence, their results are not quite accurate, but probably would not change materially if the constant term were suppressed. 
Table 1

Scaled regressions for three-digit SIC industry cross sections with U.S. net exports as dependent variable, $1958-76$.

\begin{tabular}{|c|c|c|c|c|c|c|c|}
\hline Year & $n$ & $S^{-\frac{1}{2}}$ & $K$ & $\boldsymbol{H}$ & $L$ & $R^{2}$ & $F$ \\
\hline 1958 & 119 & $\begin{array}{r}-11.61 \\
(1.36)\end{array}$ & $\begin{array}{c}-0.03 \\
(2.52)^{*}\end{array}$ & $\begin{array}{l}0.04 \\
(4.19)^{* *}\end{array}$ & $\begin{array}{c}-0.43 \\
(1.43)\end{array}$ & 0.21 & $8.66^{* *}$ \\
\hline 1959 & 117 & $\begin{array}{r}-1121 \\
(1.17)\end{array}$ & $\begin{array}{c}-0.04 \\
(3.00)^{* *}\end{array}$ & $\begin{array}{l}0.04 \\
(4.11)^{* *}\end{array}$ & $\begin{array}{c}-0.59 \\
(1.92)\end{array}$ & 0.18 & $6.36^{* *}$ \\
\hline 1960 & 117 & $\begin{array}{r}-12.85 \\
(1.30)\end{array}$ & $\begin{array}{c}-0.03 \\
(2.15)^{*}\end{array}$ & $\begin{array}{l}0.05 \\
(4.86)^{* *}\end{array}$ & $\begin{array}{l}-0.81 \\
(2.62)^{* *}\end{array}$ & 0.22 & $8.83^{* *}$ \\
\hline 1961 & 122 & $\begin{array}{c}-9.15 \\
(0.99)\end{array}$ & $\begin{array}{c}-0.03 \\
(2.22)^{*}\end{array}$ & $\begin{array}{l}0.05 \\
(5.13)^{* *}\end{array}$ & $\begin{array}{l}-0.75 \\
(2.64)^{* *}\end{array}$ & 0.23 & $9.87^{* *}$ \\
\hline 1962 & 124 & $\begin{array}{r}-14.57 \\
(1.50)\end{array}$ & $\begin{array}{l}-0.04 \\
(2.62)^{* *}\end{array}$ & $\begin{array}{c}0.05 \\
(5.45)^{* *}\end{array}$ & $\begin{array}{l}-0.72 \\
(2.66)^{* *}\end{array}$ & 0.25 & $10.75^{* *}$ \\
\hline 1963 & 123 & $\begin{array}{r}14.14 \\
(1.51)\end{array}$ & $\begin{array}{l}0.03 \\
(2.14)^{*}\end{array}$ & $\begin{array}{c}0.04 \\
(5.20)^{* *}\end{array}$ & $\begin{array}{l}-0.74 \\
(2.73)^{* *}\end{array}$ & 0.23 & $9.55^{+\infty}$ \\
\hline 1964 & 125 & $\begin{array}{c}-19.78 \\
(2.10)^{*}\end{array}$ & $\begin{array}{c}-0.03 \\
(1.76)\end{array}$ & $\begin{array}{l}0.05 \\
(5.16)^{* *}\end{array}$ & $\begin{array}{l}-0.81 \\
(2.81)^{* *}\end{array}$ & 0.24 & $10.34^{* *}$ \\
\hline 1965 & 130 & $\begin{array}{c}-21.10 \\
(2.23)^{*}\end{array}$ & $\begin{array}{c}-0.04 \\
(2.52)^{*}\end{array}$ & $\begin{array}{c}0.05 \\
(5.01)^{* *}\end{array}$ & $\begin{array}{c}-0.89 \\
(2.62)^{* *}\end{array}$ & 0.23 & $9.74^{* *}$ \\
\hline 1966 & 130 & $\begin{array}{c}-23.63 \\
(2.41)^{*}\end{array}$ & $\begin{array}{c}-0.04 \\
(2.39)^{*}\end{array}$ & $\begin{array}{c}0.04 \\
(4,44)^{* *}\end{array}$ & $\begin{array}{c}-0.77 \\
(2.27)^{*}\end{array}$ & 0.20 & $7.91^{* *}$ \\
\hline 1967 & 131 & $\begin{array}{r}-16.03 \\
(1.58)\end{array}$ & $\begin{array}{c}-0.03 \\
(2.28)^{*}\end{array}$ & $\begin{array}{c}0.04 \\
(4.27)^{* *}\end{array}$ & $\begin{array}{c}-0.86 \\
(2.41)^{*}\end{array}$ & 0.17 & $6.45^{* *}$ \\
\hline 1968 & 131 & $\begin{array}{r}-18.09 \\
(1.58)\end{array}$ & $\begin{array}{c}-0.04 \\
(2.48)^{*}\end{array}$ & $\begin{array}{c}0.04 \\
(4.18)^{* *}\end{array}$ & $\begin{array}{c}-1.01 \\
(2.55)^{*}\end{array}$ & 0.15 & $5.87^{* *}$ \\
\hline 1969 & 131 & $\begin{array}{r}-22.72 \\
(1.83)\end{array}$ & $\begin{array}{c}-0.04 \\
(2.17)^{*}\end{array}$ & $\begin{array}{l}0.05 \\
(4.55)^{* *}\end{array}$ & $\begin{array}{c}-1.14 \\
(2.80)^{* *}\end{array}$ & 0.18 & $7.06^{* *}$ \\
\hline 1970 & 131 & $\begin{array}{r}-25.60 \\
(1.83)\end{array}$ & $\begin{array}{c}-0.04 \\
(1.83)\end{array}$ & $\begin{array}{l}0.05 \\
(4.37)^{* *}\end{array}$ & $\begin{array}{l}-1.46 \\
(3.02)^{* *}\end{array}$ & 0.17 & $6.41^{* *}$ \\
\hline 1971 & 130 & $\begin{array}{r}-25.28 \\
(1.62)\end{array}$ & $\begin{array}{l}-0.05 \\
(2.27)^{* *}\end{array}$ & $\begin{array}{c}0.06 \\
(4.21)^{* *}\end{array}$ & $\begin{array}{l}-1.75 \\
(3.04)^{* *}\end{array}$ & 0.14 & $5.58^{* *}$ \\
\hline 1972 & 129 & $\begin{array}{r}-22.73 \\
(1.21)\end{array}$ & $\begin{array}{c}-0.05 \\
(1.88)\end{array}$ & $\begin{array}{c}0.05 \\
(3.16)^{* *}\end{array}$ & $\begin{array}{c}-1.76 \\
(2.48)^{*}\end{array}$ & 0.08 & $3.41 * *$ \\
\hline 1973 & 128 & $\begin{array}{r}-22.85 \\
(1.14)\end{array}$ & $\begin{array}{c}-0.06 \\
(1.87)\end{array}$ & $\begin{array}{c}0.05 \\
(3.47)^{* *}\end{array}$ & $\begin{array}{c}-1.80 \\
(2.44)^{*}\end{array}$ & 0.11 & $3.80^{* *}$ \\
\hline 1974 & 128 & $\begin{array}{r}-23.73 \\
(1.06)\end{array}$ & $\begin{array}{c}-0.08 \\
(2.19)^{*}\end{array}$ & $\begin{array}{c}0.06 \\
(3.95)^{* *}\end{array}$ & $\begin{array}{c}-2.02 \\
(2.44)^{*}\end{array}$ & 0.14 & $5.01^{* *}$ \\
\hline 1975 & 128 & $\begin{array}{r}-16.14 \\
(0.90)\end{array}$ & $\begin{array}{l}-0.08 \\
(3.08)^{* *}\end{array}$ & $\begin{array}{c}0.07 \\
(5.57)^{* *}\end{array}$ & $\begin{array}{c}-2.78 \\
(3.56)^{* *}\end{array}$ & 0.24 & $9.92^{* *}$ \\
\hline 1976 & 128 & $\begin{array}{r}-18.54 \\
(0.95)\end{array}$ & $\begin{array}{c}-0.08 \\
(2.51)^{*}\end{array}$ & $\begin{array}{l}0.06 \\
(4.68)^{* * *}\end{array}$ & $\begin{array}{l}-2.83 \\
(3.36)^{* *}\end{array}$ & 0.17 & $6.45^{* *}$ \\
\hline
\end{tabular}

and 1959. It thus appears that the three-direct-factor input model of the strliclure of U.S. net exports of manufactures is borne out for most of the years over the sample period. ${ }^{5}$

${ }^{5}$ Separate scaled regressions were run for the Heckscher-Ohlin and Product Cycle industries combined in order to determine how the results covering all industries reported in table 1 compare with those excluding the Ricardo industries. All of the variables had the same signs throughout, but the negative coefficient on physical capital was never significantly different from zero. This suggests that the results reported by Branson and Monoyios may reflect the importance of physical capital in some natural resource industries that were included in their cross sections. 
In order to get some indication of whether there were any significant changes in the regression coefficients between 1958 and 1976, we estimated a dummy-variable specification of the scaled regression with $1958=0$ and 1976 $=1$, following the procedure outlined in Kmenta $(1971$, p. 421). For all industries, the null hypothesis of no change in the coefficients was accepted for $S^{-t}, K$, and $H$ but rejected for $L$ at the 0.01 level. The coefficient on $L$ was therefore significantly more negative in 1976 as compared to 1958. This suggests that U.S. net exports of manufactures have been making less direct use of unskilled labor (as measured by industry ernoloyment) over the course of the period. 6

\subsection{Probit analysis}

Harkness and Kyle (1975) have argued that the Heckscher-Ohlin model cannot be used as a basis for analyzing the determinants of a country's net exports because it provides no guidance on what to expect concerning the effects of demand conditions as reflected in differences in industry size. As an alternative, they proposed a weaker hypothesis that industries would be either net exporters or net importers as determined by their capital labor ratios. $^{7}$ They tested this hypothesis using Baldwin's (1971) data for 1962 trade and 1958 industry characteristics by means of logit analysis. When the industries were separated into non-natural-resource industries and naturairesource industries, their results suggested a positive relation between the (physical) capital-labor ratio and the probability of an industry being a net exporter for the former and a negative relation for the latter group of industries. They concluded therefore that thcir results contradicted all previous findings of a negative relation between net exports and $K, L$ for nonnatural-resource industries.

There have been two recent attempts to validate Harkness and Kyle's results, one based upon probit analysis by Branson and Monoyios (1977) for the U.S. for 1963 and 1967, and the other based upon logit analysıs by Baum and Coe (1978) for West Germany for 1962 and 1969." In both of these studies the regression and probit/logit results agreed in that physical capital was negatively related to net exports. Our cross-section regressions for all

\footnotetext{
${ }^{6}$ We also estimated scaled regressions for exports and imports stparately for each year as well a : for each of the three major industry subgroups noted above. The results are avalable upon request.

'Baldwin (1979, p. 41) has argued that the Harkness and Kyle test is inappropriate since it is based upon the commodity version of the Heckscher-Ohlin mndel which will not hold in a multi-country world when factor prices are not equalized. He points out that the factor-content version of the model will hold in more general circumstances whether or not factor prices are equalized and that the regression procedure is therefore the correct one to follow.

${ }^{8}$ Logit analysis assumes that the cumulative density function is logistic while probit assumes it to be the integral of a normal distribution. Since the latter integral is close to logistic, the results from either method will generally be very similar.
} 
manufacturing industries summarized in table 1 all show a negative sign for phys cal capital. We ran a probit analysis for each year on our unscaled data, using the levels of $K, H$, and $L$ as explanatory variables and also using $K / L$ and $H / L$ as explanatory variables. The sign of $K$ and $K / L$ was negative in every year without exception.

In order to examine Harkness and Kyle's claim about the distinction between natural-resource and non-natural-resource industries, we then ran a probit analysis for each year for the Heckscher-Ohlin and Product Cycle industries combined and with the Ricardo industries eliminated, using $K / L$ and $H / L$ as explanatory variables. In every year the signs of both variables were positive, although $K / L$ was never statistically significant. The results for 1958, 1967, and 1976 are summarized in table 2. It thus appears that the negative sign for $K / L$ reported by Branson and Monoyios for their 1963 and 1967 probit analyses may reflect the presence of natural resource industries in their data sample. Harkness and Kyle may therefore be correct in finding a positive relation between $K / L$ and the probability of a non-natural-resource

Table 2

Probit analysis of U.S. net exports of manufactures. ${ }^{a}$

\begin{tabular}{lccc}
\hline \multicolumn{4}{c}{ Independent variables } \\
\cline { 1 - 2 } Year & $K / L$ & $H / L$ & $-2 \log \lambda$ \\
\hline All manufactures & & & \\
1958 & -0.022 & 0.050 & $13.411^{* *}$ \\
& $(1.99)$ & $(3.49)^{* *}$ & \\
1967 & -0.017 & 0.046 & $21.800^{* *}$ \\
& $(2.22)^{*}$ & $(4.44)^{* *}$ & \\
1976 & -0.015 & 0.018 & $13.430^{* *}$ \\
& $(2.25)^{*}$ & $(3.51)^{* *}$ & \\
Excluding Ricardo & & & \\
industries & & & \\
1958 & 0.017 & 0.059 & $26.53^{* *}$ \\
& $(0.95)$ & $(3.96)^{* *}$ & \\
1967 & 0.012 & 0.051 & $33.48^{* *}$ \\
& $(0.81)$ & $(4.78)^{* *}$ & \\
1976 & 0.003 & 0.023 & $28.55^{* *}$ \\
& $(0.29)$ & $(4.35)^{* *}$ & \\
\hline
\end{tabular}

${ }^{2}$ The numbers in parentheses are the probit coefficients divided by their standard errors. Significance levels are based on a table of $t$ values and hence are only approximate here. The final column reflects the difference in a log transformation of the likelihood ratio $\lambda$; the statistic $-2 \log \lambda$ is distributed as chi-squared in large samples and the reported significance levels reflect this fact. This latter statistic is analogous to a regression $F$-statistic in that it tests for the existence of an overall relationship. 
industry being a net exporter, using their data set for 1962 trade and 1958 industry characteristics.

\section{Direct factor inputs and technological influences on U.S. trade in manufactures, 1960 and 1970}

We next sought to broaden the model by constructing somewhat more refined measures of human capital using census data for 1960 and 1970 on education and earnings by industry and introducing selected data on technological influences that are not readily available unnually. Human capital was broken down by years of education for employees with 0-8, 9-12, and $13+$ years in each census industry and $e \mathrm{ch}$ of the measures was included separately and in combination. The fir st medstre based on 0.8 years of education would reflect unskilled labor compared to the measures based on 9-12 and 13+ years of education. The best results were obtained when the measures were divided into 0-8 and 9-13+ years of education.

In table 3 we present some selected results for 1960 and 1970. Eqs. (3.1) and (3.7) repeat the regressions based upon three-factor inputs reported in table 1 . Only the human-capital variable was statistically significant in these equations. Eqs. (3.2) and (3.8) contain separate variable; for $H K_{1}$ and $H K_{2}$, which refer respectively to the annual wage differentials for employees with 0-8 and 9-13+ years in each industry vis-à-vis the unskilled wage for workers in all industries, discounted at 10 percent and multiplied by the relevant industry employment as in eq. (2) in the text above. It is evident that the signs on $H K_{1}$ and $L$ are both negative and the sign on $H K_{2}$ is positive, which reinforces the idea that U.S. net exports are intensive in human capital relative to unskilled labor. The coefficients on all three of these variables were statistically significant in 1970 as noted in eqs. (3.10) and (3.12) while only $H K_{2}$ was significant in 1960. The physical capital variable was not significant in either year. The results for 1970 thus suggest that both skill differences as measured by the discoun ed wage differentials based upon years of education together with indusiry employment are significant determinants of U.S. net exports of manufactures.

The theory of the Product Cycle suggests the importance of technological influences in determining the composition of net exports. While it was not possible to construct technological measures on an annual basis for the three-digit industries analyzed earlier, the 1960 and 1970 census data provided information on the numbers of engineers and scientists by industry. Baldwin (1971) found this to be significant in his analysis of 1962 trade. We also constructed a measure of research and development expenditures by industry. The expectation is that these technologica! influences will be positively related to net exports. This is borne out in eqs. (3.3)-(3.6) for 1960 and (3.9)-(3.12) for 1970. Engineers and scientists were expressed as a 


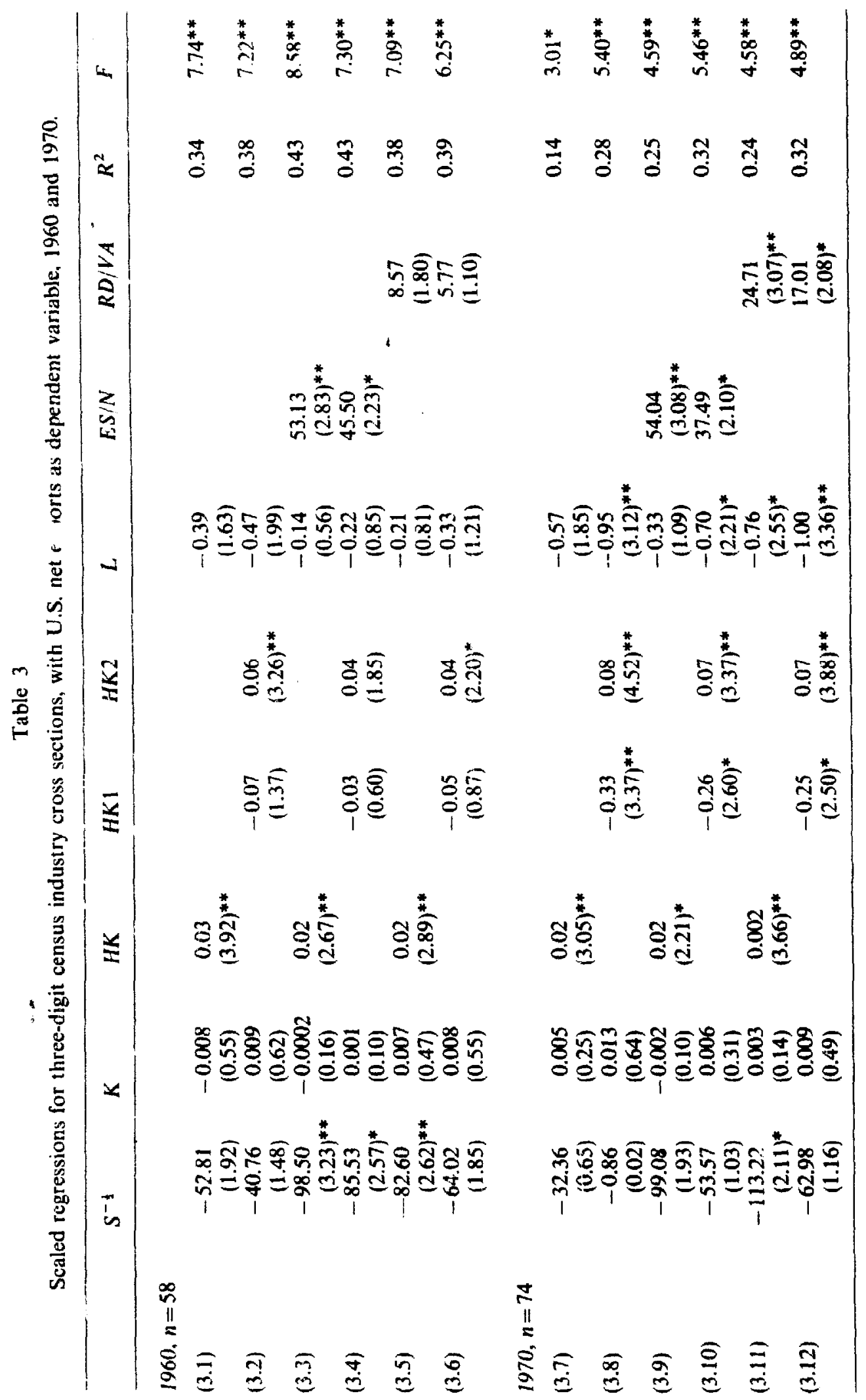


percentage of total industry employment $(E S / N)$ and research and development expenditures as a percentage of industry value added $\left(R D / l^{\prime} A\right)$. It is noteworthy that the best results were obtained in eqs. (3.10) and (3.12) for 1970. These results suggest that U.S. net exports of manufactures embody the direct services of human capital together with technological inputs relative to unskilled labor and physical capital. We tested the various equations to determine if the coefficients had changed between 1960 and 1970. There was some (weak) evidence thet the coefficient on labor had become more negative, which bears out our previous results, and that the coefficient on $R D / V A$ had become more positive. ${ }^{9}$

\section{Factor content (direct plus indirect) of total U.S. imports and exports, 1958 and 1972}

Our analysis to this point has focused on the dicect-factor content of U.S. trade in manufactures and has ignored both the indirect use of factor inputs as well as trade in non-manufactures. We will now take these considerations into account. For this purpose, we have relied upon the 79 -sector versions of the 1958 and 1972 input-output tables. We first calculated the factor requirements per million dollars of exports and competitive impor: replacements for all industries. We then repeated the calculations, omitting sequentially the service industries, then agriculture, forestry and fisheries, mining and construction, and, finally, the natural resource industries. In each of the sequential calculations only the direct-factor coefficients and the import-export coefficients were set equal to zero. The indirect effects associated with these sectors thus remain in the calculations since they are relevant to the factor content of trade that is covered.

The results are summarized in table 4 . In 1958 the import-export ratio of gross physical capital to labor $(K / L)$ was 1.07 for all industries and above unity for all the other sequential measures. This indicates the presence of the Leontief paradox for 1958, which is also what Baldwin found (1971, p. 134). In 1972 , however, this ratio was 0.95 , which suggests that U.S. exports were relatively intensive in physical capital and therefore that the Leontief paradox is not observed in this later year. This was the case also when the agriculture, etc. and natural resource sectors were removed. The results

\footnotetext{
${ }^{9}$ Further results, which are not reported here, indicated a high degree of multi-collinearity when $E S / N$ and $R D ; V A$ were lacluded in the same equation. This would be expected since these are alternative measures of the same technological phenomena. We also adapted Hufbauer's (1970) measures of industry concentration, scale economies, the consumer goods ratio, first trade date, and product difierentiation to both 1960 and 1970 in order to determine if the influences of these added industry and product characteristics could be identified separately or in combination. None of these additional variables was significant. Further research might therefore be warranted to determine whether and how these additional influences are reflected in U.S. net exporis in conjunction with the physical capital, human capital. employment, and technological variables that we have considered.
} 


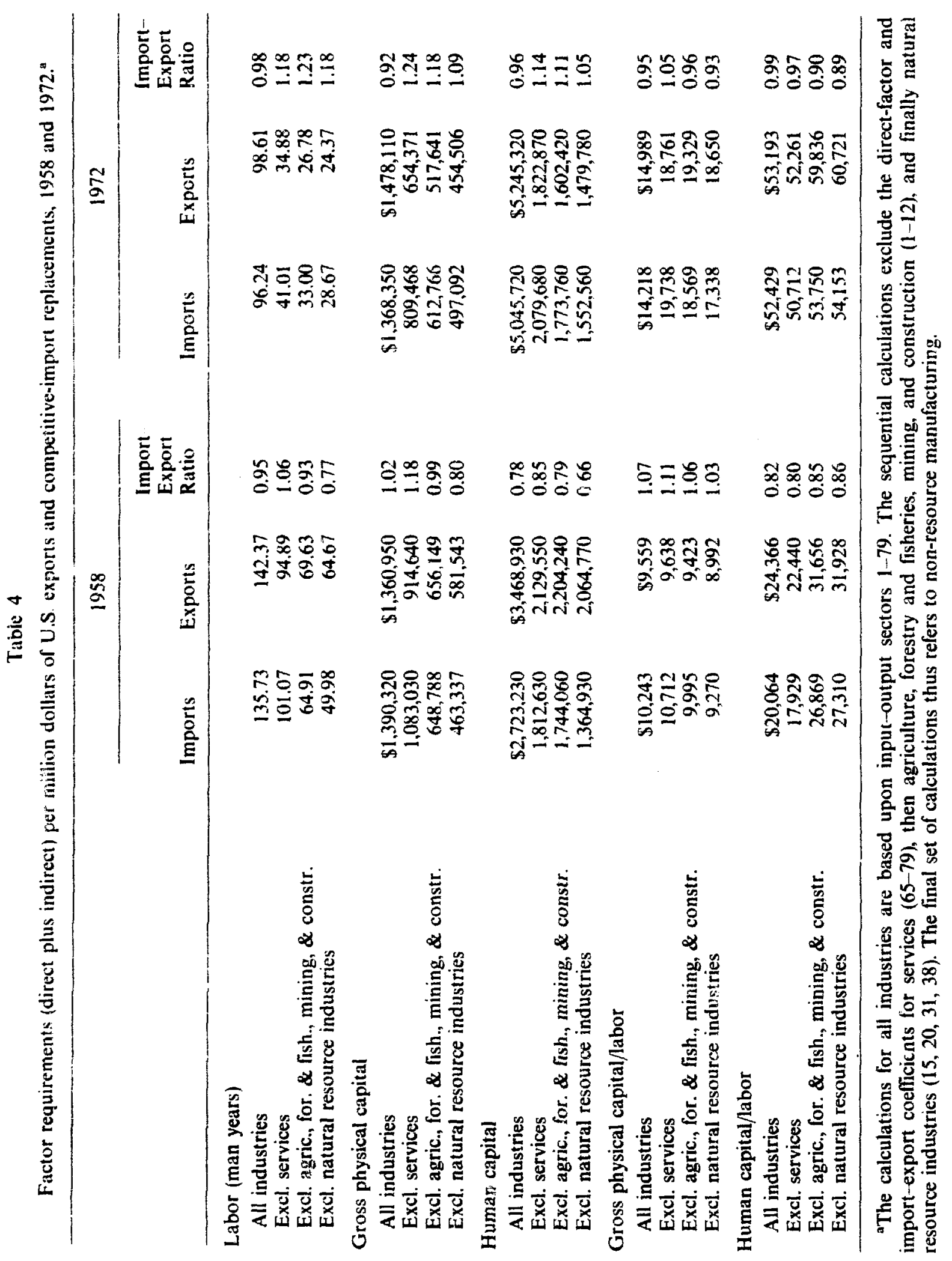


indicate further that the import-export ratio of human capital to labor $(H / L$, was 0.82 for all industries in 1958 and 0.99 in 1972. Elimination of the various sectors tended to raise the import-export ratio for $H / L$ somewhat in 1958 and to lower it in 1972. It thus appears that U.S. exports in 1958 were relatively more intensive in labor and human capital compared to imports, but that, in 1972, exports were relatively more intensive in physical capital and human capital.

Since our earlier regression and probit results were based upon direct factor inputs for trade in manufactures, it is of interest to determine what the effect would be of including indirect inputs as well as trade in nonmanufactures. For this purpose it was necessury to change the dependent variable to conform with the input measures in terms of requirements per million dollars of output. We therefore calculated what Baldwin (1971, p. 133) has called 'net adjusted trade balances'. Thus, each industry's exports and competitive imports were adjusted by multiplying their respective shares of total exports and imports by one million dollars. Net exports by industry were then equal to the differences between these adjusted values. The independent variables were expressed as ratios, $K / L$ and $H / L$, in order to correspond to the formulation used by Baldwin and Harkness and Kyle.

The equations were first estimated based upon unscaled variables and then tested for the presence of heteroskedasticity, which was confirmed. We then scaled the data, by $S$. The results for 1958 and 1972 are summarized in table 5. Eqs. (5.2) and (5.3) are probably closest to what Baldwin did and bear out his findings of a negative coefficient on $K / L$ and a positive coefficient on $H / L$. For 1972 , none of the coefficients was significantly different from zero so that the regression results for this year cannot be compared directly to the import-export ratios calculated in table 4.

The probit results, which are not reproduced here, disclosed that the coefficients on $K / L$ were generally not statistically significant in either year, although their sign became positive when natural resource industries were eliminated. The coefficients on $H / L$ were positive and significant in both years. These probit results thus bear out (weakly) those obtained using only direct-factor requirements for trade in manufactures, and there is a suggestion again that the elimination of natural-resource industries may account for the difference in results obtained by Harkness and Kyle and Branson and Monoyios. ${ }^{10}$

\section{Factor content (direct plus indirect) of U.S. net exports and consumption, 1958 and 1972}

Leamer (1980) has argued that the Leontief-type calculations of the factor

\footnotetext{
${ }^{10}$ Our probit findings should not be construed to support the formulation used by Harkness and Kyle since, as noted previously, the regression procedure is the correct one to follow based upon the factor-content version of the Heckscher-Ohlin model.
} 
Table 5

Scalcu regressions of ne: adjusted U.S. trade balances on ratios of total factor requirements by industry, 1958 and 1972.

\begin{tabular}{|c|c|c|c|c|c|}
\hline & $S^{-1}$ & $K / L$ & $H / L$ & $R^{2}$ & $F$ \\
\hline \multicolumn{6}{|l|}{1958} \\
\hline (5.1) All sectors & $\begin{array}{r}-968.4 \\
(0.24)\end{array}$ & $\begin{array}{c}-1.20 \\
(1.82)\end{array}$ & $\begin{array}{l}0.51 \\
(2.05)^{*}\end{array}$ & 0.07 & 2.99 \\
\hline (5.2) Excluding services & $\begin{array}{l}3777.5 \\
\quad(0.84)\end{array}$ & $\begin{array}{l}-1.68 \\
(4.42)^{* *}\end{array}$ & $\begin{array}{l}0.41 \\
(2.84)^{* *}\end{array}$ & 0.26 & $7.27^{* *}$ \\
\hline $\begin{array}{l}\text { (5.3) Excluding agriculiure. } \\
\text { forestry and fisheries, } \\
\text { mining and construction }\end{array}$ & $\begin{array}{r}-8835.3 \\
(1.31)\end{array}$ & $\begin{array}{l}-1.38 \\
(2.87)^{* *}\end{array}$ & $\begin{array}{l}0.70 \\
(2.74)^{* *}\end{array}$ & 0.12 & $3.61^{*}$ \\
\hline $\begin{array}{l}\text { (5.4) Excluding n tura! } \\
\text { resource industrics }\end{array}$ & $\begin{array}{r}-11694.0 \\
(2.05)^{*}\end{array}$ & $\begin{array}{l}-0.44 \\
\left(0 . .^{\prime}\right)\end{array}$ & $\begin{array}{l}0.63 \\
(3.02)^{* *}\end{array}$ & 0.19 & $4.48^{* *}$ \\
\hline \multicolumn{6}{|l|}{1972} \\
\hline (5.5) All sectors & $\begin{aligned}-1703.6 \\
(0.43)\end{aligned}$ & $\begin{array}{c}0.20 \\
(1.10)\end{array}$ & $\begin{array}{c}-0.02 \\
(0.58)\end{array}$ & 0.02 & 0.64 \\
\hline (5.6) Excluding services & $\begin{array}{r}-5822.3 \\
(1.61)\end{array}$ & $\begin{array}{r}-0.10 \\
(1.37)\end{array}$ & $\begin{array}{c}0.16 \\
(1.80)\end{array}$ & 0.06 & 1.14 \\
\hline $\begin{array}{l}\text { (5.7) Excluding agriculture, } \\
\text { forestry and fisheries, } \\
\text { mining and construction }\end{array}$ & $\begin{array}{r}-6784.5 \\
(1.60)\end{array}$ & $\begin{array}{c}0.03 \\
(0.16)\end{array}$ & $\begin{array}{c}0.15 \\
(1.59)\end{array}$ & 0.10 & 1.28 \\
\hline $\begin{array}{l}\text { (5.8) Excluding natural } \\
\text { sesource industries }\end{array}$ & $\begin{array}{r}-6103.8 \\
\quad(1.53)\end{array}$ & $\begin{array}{c}0.09 \\
(0.42)\end{array}$ & $\begin{array}{c}0.13 \\
(1.43)\end{array}$ & 0.10 & 1.33 \\
\hline
\end{tabular}

requirements of trade that we have just examined are misleading if more than two commodities exist. According to the Leontief criterion, a country is revealed to be capital abundant if the capital per worker embodied in exports is greater than in imports. Based upon Vanek's (1968) generalization of the Heckscher-Ohlin model to $n$ goods and factors, Leamer contends that the Leontief criterion would hold in the many-commodity case only if the net export of capital services were positive and the net export of labor services were negative. A problem arises because, as can be seen for 1958 in table 6, the net exper:s of both factor services may have the same sign. The proper compa ison therefore is between capital per man embodied in net exports and capital per man in consumption. If the former exceeds the latter, then the U.S. is revealed to be relatively abundant in physical capital.

We calculated these relationships using our data and the input-output iables for 1958 and 1972. In the absence of production data by sector, we used the value of shipments. This has the familiar disadvantage of double counting. But since we are interested in factor-use ratios, the particular measure of output chosen should not undermine the efficacy of the tests unless there is some systematic bias in the relationship between sectoral measures of shipments and value added. In any event, the results are summarized in table 6 . 
Tuble 6

Factor content (direct plus indirect) of total U.S. production, net exports, and consumption, 1958 and 1972.

\begin{tabular}{|c|c|c|c|}
\hline & Production $^{a}$ & Net exports & Consumption" \\
\hline \multicolumn{4}{|l|}{1958} \\
\hline Labor (mill. man years) & 108.72 & 1.38 & 107.34 \\
\hline Gross physical capital (\$mill.) & $\$ 1,003,217$ & $\$ 11,901$ & $\$ 991,316$ \\
\hline Human capital (\$mill.) & $\$ 2,338,489$ & $\$ 36,305$ & $\$ 2,302,184$ \\
\hline Gross physical capital/labor & $\$ 9,228$ & $\$ 8,624$ & $\$ 9.23 \mathrm{~J}$ \\
\hline Human capital/labor & $\$ 21,509$ & $\$ 26,308$ & $\$ 21,448$ \\
\hline Human capital/gross physical capital & 2.331 & 3.051 & 2.322 \\
\hline \multicolumn{4}{|l|}{1972} \\
\hline Labor (mill. man years) & 228.52 & -0.43 & 228.95 \\
\hline Gross physical capital (\$mill.) & $\$ 3.163 .347$ & $-\$ 2,258$ & $\$ 3,165,605$ \\
\hline Human capital (\$mill.) & $\$ 11,184,588$ & $-\$ 16,178$ & $\$ 11,200,766$ \\
\hline Gross physical capital/labor & $\$ 13,843$ & $\$ 5,251$ & $\$ 13,827$ \\
\hline Human capital/labor & $\$ 48,944$ & $\$ 37,623$ & $\$ 48,922$ \\
\hline Human capital/gross physical capital & 3.536 & 7.165 & 3.538 \\
\hline
\end{tabular}

${ }^{\mathrm{a}} \mathrm{Ba}$ ind upon value of shipments, which reflect double counting of intermediate inputs.

${ }^{b}$ Calcilated as the difference between production and net exports.

It is evident that in 1958 the U.S. was a net exporter of all three factor services considered and that it was a net importer of these services in 1972. For 1958, if we compare net exports to consumption with respect to the ratio of physical capital to labor, the results suggest that the Leontief paradox holds. For 1972, wits the net import of the factor services, the appropriate comparison between net exports and consumption will be the reverse. That is to say, the U.S. would be considered relatively well endowed in capital compared to labor if the capital-labor ratio in net exports were less than in consumption. We se that this is indeed the case in 1972. Hence, there is strong evidence of a reversal in the paradox in the later year, which is consistent with the findings in table 4 .

As for human capital, the results for 1958 suggest a relative abundance visà-vis both labor and physical capital. Since in 1972 the net exports of all factors are negative, the smailer human capital-labor ratio in net exports relativè to consumption indicates an abundance of human capital vis-à-vis labo:. On the other hand, considering the final row in table 6, it appears that, according to our data, the U.S. has become relatively more abundant in physical capital as compared to human capital.

Leamer (1980) made some calculations based upon Leontief's findings for 1947 trade and found that the ratio of physical capital to labor was higher in net exports than in consumption. He concluded therefore that the Leontief paradox did not hold for 1947. Ou: calculations in both tables 4 and 6 
support the Leontief paradox for 1958 but not for 1972. It is possible of course that our data are deficient and that the results would change with a more accurate measure of production by sector. In any case, our data and results for 1972 suggest that U.S. net exports are relatively intensive in both physical and human capital as compared to labor and that the abundance of physical capital has increased relative to human capital since 1958.

\section{Summary and conclusions}

In this paper we have analyzed several different aspects of the direct factor content of U.S. trade in manufactures over the period 1958-76, and the total factor requirements (direct plus indirect) of U.S. trade for all sectors. Our major findings can be summarized as follows.

(1) The three-direct-factor input model provides a reasonable interpretation of U.S. trade in manufactures, but the observed negative sign on physical capital may be due to the inclusion of natural-resource industries in the data sample.

(2) The anrual cross-section results are positive for human capital and negative for unskilled labor with respect to industry trade balances. The negative influence of labor has become more pronounced over the period.

(3) The three-direct-factor input model was also borne out using census data for 1960 and 1970 , especially with regard to somewhat more refined measures of h:ıman capital based on years of education. These results also demonstrated clearly the importance of technological influences on U.S. trade in manufactures in terms of considerations associated with the theory of the product cycle.

(4) Our analysis of the total factor requirements of U.S. trade suggests that the Leontief paradox held for 1958 but not for 1972 . This was the case when the factor requirements were zompared in terms of the import-export ratio as in the original Leontief test and when the factor requirements of net exports were compared to consumption based on the generalization of the Heckscher-Ohlin model to a many-commodity world. It thus appears that in 1972 U.S. net exports were intensive in both physical and human capital in terms of total factor requirements, although this conclusion was not supported in the regressions that we ran. Finally, our data suggest that the U.S. may have become relatively more abundant in physical capital relative to human capital between 1958 and 1972. However, our regression results for trade in mantiactures reveal the dominance of human capital and labor.

If we consider the pericd as a whole, our results suggest that there are two important changes that have occurred which merit further investigation. The first involves the significantly larger negative influence of unskilled labor reflected in the net exports of manufactures, and the second is that the Leontie paradox is no longer evid nt. The larger negative influence of 
urskilled labor may reflect technological developments in export industries which rely relatively more on human capital as well as grealer imports. especially of Heckscher-Ohlin type manufactures which are labor intensive. The fact that we do not observe the Leontief paradox in 1972 as compared to 1958 no doubt reflects changes in the composition of trade that occurred in the intervening years, especially the decine in the relative importarice of the imports of Ricardo (natural resourcei goods.

\section{Appendix: Data sources}

Data on the values of exports and imports by three-digit SIC industry for 1958-72 were obtained from the annual piblications of the Bureau of the Census. U.S. Commodity Exp.rts and Imports as Related to Output, and for 1973-76 from the annual publications of the Bureau of the Census, U.S. Exports/Domestic Merchandise, SIC-Based Products by World Areas. Report FT 210.

The classification of three-digit SIC industries into Ricardo, HeckscherOhlin, and Product Cycle goods was based upon Hufbauer and Chilas (1974. pp. 35-38). Data on employment and total payrolls by SIC industry were taken from various issues of the Bureau of the Census, Annual Survey of Manufactures. Data on the value of shipments by SIC industry for 1958-71 were obtained from the annual publications, U.S. Commodity Exports and Imports as Related to Output, and for 1972-76 from the Annual Survey of Manufactures: Industry Profiles (1976).

The capital-stock data by three-digit SIC industry refer to gross stock s unadjusted for depreciation. The nominal and constant dollar (1958) capital stocks by industry for $1958-71$ were taken from U.S. General Services Administration, Office of Emergency Preparedness, Capital Stocks Figures (Final), Input-Output Sectors, SIC Level with Vintage (May 1974). These data were extended to 1972-76 using information on the book value of fixed assets by industry contained in the Annual Survey of Manufactures: Industry Profiles (1976).

The values of exports, imports, and shipments were converted to constant (1967) dollars by means of price deflators constructed for each three-digit SIC industry. These deflators were based upon data taken from various issues of U.S. Bureau of Lator Statistics, Wholesale Prices and Price Indexes.

To construct our measure of human capital, the wage of unskilled labor was taken as the median income of persons aged 25 and over of all races and both sexes, with eight or less years of schooling. This measure was constructed from various issues of the U.S. Bureau of Census, Current Population Report: Consumer Income, Series P-60.

The estimates of human capital and the number of enginecrs and scientists for the 1960 and 1970 three-digit SIC industry cross sections were 
constructed from U.S. Bureau of the Census, U.S. Census of Population: 1960, Final Report $\mathrm{FC}(2)-7 A$, Occupational Characteristics, Table 32: U.S. Census of Population: 1960, Occupation by Industry, Final Report PC(2) 7C, Table 2; U.S. Census of Population: 1970, Subject Reports, Final Fieport $P C(2)-8 B$, Earnings by Occupation and Education; and U.S. Census of Population: 1970, Occupation by Industry, Final Report PC(2) - 7C. The estimates of research and development expenditures by industry for 1960 and 1970 were based upon National Science Foundation, Research and Development in Inilustry 1971.

The input-output data used were based upon the 79-industry classification in the total requirements tables for 1958 as published in the September 1965 issue of the Survey of Current Business (SCB) and for 1972 as published in the April 1979 SCB. The direct labor-output, capital-output, and human capital-output coefficients were calculated from a variety of sources.

There were numerous instances in which the data had to be approximated, imputed, weighted, and concorded to an SIC basis. Details are available on request.

\section{References}

Baldwin. R.E., 1971. Determinants of the commodity structure of U.S. trade, American Economic Review 61, March, 126-146.

Baldwin, R.E., 1979, Determinants of trade and foreign investment: Further evidence, Review of Economics and Statistics 61, February, 40-48.

Baum, C.F. and D. Coc, 1978, A logit analysis of the factor content of West Germany's foreign trade, Weltwirtschaftliches Archiv 1I4, no. 2.

Branson, W.H. and N. Monoyios, 1977, Factor inputs in U.S. trade, Journal of International Economics 7, May, 111-131.

Harkness, J. and J.F. Kyle, 1975, Factors influencing United States comparative advantage, Journal of International Economics 5, May, 153-165.

Hufbauer, G.C., 1970, The impact of national characteristics and technology on the commodity composition of trade in manufactured goods, in: R. Vernon, ed., The technology factor in world trade (Colu:nbia University Press, New York) 145-232.

Hufbauer, G.C. and J.G. Chillas, 1974, Specialization by indust:ial countries: Extent and consequences, in: $\mathbf{H}$. Giersch, ed., The international division of labour: Problems and prospects (J.C.B. Mohr, Tubingen) 3-38.

Kmenta, J., 1971, Elements of econometrics (Macmillan, New York).

Leamer, E.E., 1980, The Leontief paradox, reconsidered, Journal of Political Economy 88, June, 495-503.

Sterr, R.M., 1976, Some evidence on the factor content of West Germany's foreign trade, surnal of Political Economy 84. February, 131-141.

Vari $\leq, 3 ., 1968$, The factor proportions theory: The $n$-factor case, Kylios 21, October, 749-756. 